\title{
Effect of aerosol propellants and surfactants on airway resistance
}

\author{
G. M. STERLING ${ }^{1}$ A ND J.C. BATTEN \\ From St. George's Hospital, London, S.W.I
}

\begin{abstract}
The effects on the airways of inhalation of the vehicles used in two commercial pressurized bronchodilator aerosols were studied in 20 normal and seven asthmatic subjects. Changes in bronchial calibre due to bronchoconstriction were measured as changes in airway resistance using a constant volume whole body plethysmograph, and results were expressed as changes in the ratio Airway conductance/Thoracic gas volume (=specific airway conductance). The aerosols caused very slight bronchoconstriction in the normal subjects, with a mean decrease of $5.3 \%$ in specific airway conductance after inhalation of a spray containing sorbitol trioleate as a surface tension lowering agent, and of $\mathbf{9 \cdot 7} \%$ after inhalation of a spray containing lecithin. This effect was prevented by prior inhalation of atropine methonitrate, and its mechanism was therefore probably a vagally mediated reflex. The bronchoconstriction was also reversed by the addition of isoprenaline to the aerosol. The asthmatic subjects showed larger mean reductions in specific airway conductance of $13 \%$ and $21 \%$ after sorbitol and lecithin respectively: the response was again prevented by atropine. We conclude that, although the aerosol vehicles cause slight bronchoconstriction, this is unlikely to be a clinical danger since it is insufficient to cause symptoms of wheezing, and is less than that caused by inhalation of a single cigarette. Moreover, the constriction is regularly convented to dilatation in both normal and asthmatic subjects by the addition of atropine or isoprenaline to the aerosol.
\end{abstract}

There have recently been several reports of asthmatic deaths associated with the use of pressurized catecholamine aerosols (Keighley, 1966 ; Pickvance, 1967 ; Greenberg and Pines, 1967), and there is statistical evidence that there has been an increase in the death rate from asthma, particularly among young patients, since the introduction of these aerosols (Speizer, Doll, and Heaf, 1968a; Speizer, Doll, Heaf, and Strang, 1968b). The cause of the asthmatic deaths is unknown, but if it is connected with the use of aerosols it could be due either to overdosage with catecholamines or to toxicity or bronchoconstriction from the vehicles used in the sprays (Plaut, 1967; Freedman, 1967 ; Valtonen, 1967). The present study was undertaken to investigate the effect of these vehicles on bronchoconstriction in normal and asthmatic subjects.

\section{MATERIAL AND METHODS}

AEROSOLS The active agent in a pressurized aerosol is carried in an inert propellant, to which is added a

1Present address; University Laboratory of Physiology, Oxford surface-tension lowering agent to maintain fairly even small droplet size. The propellants are usually halo은 genated hydrocarbons which are normally gaseous but easily liquefied, at room temperature. They have been investigated previously and found to be non 3 . toxic (Kubler, 1964), though broncho-constrictor activity does not seem to have been excluded. In the present study the main propellant used was dichlordifluoroethane throughout, but the surfactant was varied for comparison. The two investigated were sorbitol trioleate, which is used in an isoprenaline. spray (Medihaler Iso ; Riker) and soya lecithin, whichN is used in an orciprenaline spray (Alupent ; Boehringer Ingelheim).

AIRWAY RESISTANCE Airway resistance (Raw) was measured using a constant volume whole body plethysmograph as described in detail previously (Du든 Bois, Botelho, Bedell, Marshall, and Comroe, 1956 . DuBois, Botelho, and Comroe, 1956). The subjects sat in the plethysmograph, and after warming up for two or three minutes performed short bursts of shallow? panting respiration through a heated flowmeter (Fleisch pneumotachograph) which could be closed的 by a remotely controlled shutter while gentle respiratory efforts were continued. The resulting flow $/<$ plethysmograph pressure and mouth pressure $/ \&$ 
plethysmograph pressure signals were displayed as narrow, almost linear, vector loops on an oscilloscope. Their slopes were measured by visual alignment with a ruled Perspex disc which rotated within a fixed protractor scale in front of the oscilloscope screen. Each value of airway resistance was calculated from the mean of five successive short bursts of panting, and after subtraction of $0.45 \mathrm{~cm} . \mathrm{H}_{2} \mathrm{O} / 1$. $/ \mathrm{sec}$. for the resistance of the pneumotachograph, Raw was converted to its reciprocal, airway conductance (Gaw). Thoracic gas volume (Vtg) was measured during the performance of respiratory efforts against the closed shutter, and was used to correct conductance, which has been found to increase almost linearly with increasing lung volume (Briscoe and DuBois, 1958 ; Butler, Caro, Alcala, and Dubois, 1960 ; Guyatt, Alpers, Hill, and Bramley, 1967). Results were finally expressed as changes in the ratio $\mathrm{Gaw} / \mathrm{Vtg}$, which is specific conductance (SGaw).

\section{PROCEDURE}

During each test, the subject practised shallow panting until he could produce consistent vector slopes, and a control value of SGaw was then measured. A second value was obtained shortly (within 90 seconds) after the inhalation of 10 deep breaths of an aerosol consisting of dichlordifluoroethane, with either sorbitol trioleate or soya lecithin as a surfactant. After a rest of 15 minutes the whole procedure was repeated with the other surfactant in the same propellant. The test was semi-blind in that the operator who was reading the angles of the vector loops did not know the order in which the aerosols were inhaled until he was told by the subject at the end. If a change in SGaw lasted for more than 15 minutes, the rest period between inhalations was prolonged until SGaw had returned to its control value $\pm 10 \%$, so that all tests started from a similar resting state.

\section{SUBJECTS}

Twenty normal adults were studied before and after inhalation of aerosols containing sorbitol trioleate and lecithin as surfactant. A smaller group of 13 was selected on grounds of availability and consistency of results, and the response of these to the aerosols was studied again after the inhalation of five breaths of another aerosol containing atropine methonitrate $0.04 \mathrm{mg}$. per puff. Nine normal subjects were also studied after the inhalation of three breaths of a standard isoprenaline spray (Medihaler Iso ; Riker).

Seven asthmatic subjects were studied before and after inhalation of the sorbitol trioleate and lecithin aerosols, and the tests were repeated on five of them after inhalation of atropine.

It was ensured that none of the subjects had smoked for 90 minutes before starting a test in view of the bronchoconstrictor action of cigarette smoke (Nadel and Comroe, 1961 ; Zamel, Youssef, and Prime, 1963 ; Sterling, 1967).

\section{RESULTS}

Tables I and II show the effect of inhalation of aerosols containing only dichlordifluoroethane and either lecithin or sorbitol trioleate. There was a slight fall in mean airway conductance with both surfactants; a slightly larger response occurred after lecithin, but this was not significantly different from that seen after sorbitol trioleate $(t=1 \cdot 6$,

T A B L E I

\begin{tabular}{|c|c|c|c|c|c|}
\hline \multirow{2}{*}{$\begin{array}{l}\text { Aero- } \\
\text { sol }\end{array}$} & \multirow{2}{*}{$\begin{array}{l}\text { Sub- } \\
\text { jects }\end{array}$} & \multicolumn{2}{|c|}{ Mean SGaw \pm S.D. } & \multirow{2}{*}{ Change } & \multirow{2}{*}{$\begin{array}{c}\text { Signifi- } \\
\text { cance }\end{array}$} \\
\hline & & Before & After & & \\
\hline $\begin{array}{l}\text { Sorbi- } \\
\text { tol } \\
\text { Leci- }\end{array}$ & 20 & $0.220 \pm 0.056$ & $0.206 \pm 0.049$ & $-5 \cdot 34$ & $0.1>P>0.05$ \\
\hline & 20 & $0 \cdot 214 \pm 0.058$ & $0.192 \pm 0.048$ & $-9 \cdot 71$ & $P<0.001$ \\
\hline
\end{tabular}

T A B L E I I

\begin{tabular}{|c|c|c|c|c|}
\hline Aerosol & $\begin{array}{l}\text { Sub- } \\
\text { jects }\end{array}$ & $\begin{array}{l}\text { Mean \% Change } \\
\text { in SGaw }\end{array}$ & \multicolumn{2}{|c|}{ Significance } \\
\hline $\begin{array}{c}\text { Before atropine } \\
\text { Sorbitol } \\
\text { Lecithin }\end{array}$ & $\begin{array}{l}13 \\
13\end{array}$ & $\begin{array}{r}-6.62 \\
-11.68\end{array}$ & $\begin{array}{l}t=2 \cdot 14 \\
t=3 \cdot 38\end{array}$ & $\begin{array}{c}0.1>P>0.05 \\
P<0.01\end{array}$ \\
\hline Atropine & 13 & +40.09 & $t=11.73$ & $P<0.001$ \\
\hline $\begin{array}{c}\text { After atropine } \\
\text { Sorbitol } \\
\text { Lecithin }\end{array} \quad \ldots$ & $\begin{array}{l}13 \\
13\end{array}$ & $\begin{array}{l}-0.11 \\
+0.48\end{array}$ & $\begin{array}{l}t=0.08 \\
t=0.46\end{array}$ & $\begin{array}{l}P>0.95 \\
P>0.70\end{array}$ \\
\hline Isoprenaline .. & 9 & $+34 \cdot 2$ & $t=9.89$ & $P<0.001$ \\
\hline
\end{tabular}

$P>0 \cdot 1)$. The changes were present within one minute of the inhalation and usually wore off within five minutes. suggesting that they were caused by bronchial muscle contraction rather than by bronchial oedema or excess mucus secretion. The mechanism of this bronchoconstriction was investigated by repeating the test after inhalation of not more than $0.2 \mathrm{mg}$. of atropine methonitrate. This caused bronchodilatation and prevented any constrictor response to subsequent inhalations of the dummy aerosols (Table II). The effect of an isoprenaline aerosol containing sorbitol is also shown in Table II ; there was a consistent rise in SGaw, indicating bronchodilatation.

\section{T A B L E I I I}

\begin{tabular}{|c|c|c|c|c|}
\hline Aerosol & & Subjects & $\begin{array}{c}\text { Mean \% Change } \\
\text { in SGaw }\end{array}$ & Significance \\
\hline $\begin{array}{l}\text { Before atropine } \\
\text { Sorbitol } \\
\text { Lecithin }\end{array}$ & $\ldots$ & $\begin{array}{l}7 \\
7\end{array}$ & $\begin{array}{l}-13 \cdot 49 \\
-21 \cdot 33\end{array}$ & $\begin{array}{l}t=2.67 \quad P<0.05 \\
t=3.35 P<0.02\end{array}$ \\
\hline Atropine & . & 5 & $+64 \cdot 70$ & $t=4.31 P<0.02$ \\
\hline $\begin{array}{l}\text { After atropine } \\
\text { Sorbitol } \\
\text { Lecithin }\end{array}$ & 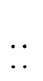 & $\begin{array}{l}5 \\
5\end{array}$ & $\begin{array}{l}+1 \cdot 16 \\
+1 \cdot 98\end{array}$ & $\begin{array}{l}t=0.40 \quad P>0.8 \\
t=0.74 P>0.6\end{array}$ \\
\hline
\end{tabular}


In the asthmatic subjects, the dummy aerosols caused slightly greater bronchoconstriction than in the normal ones, but the effect was again prevented by prior inhalation of atropine (Table III).

\section{DISCUSSION}

There is some statistical evidence (Smith, 1966; Speizer et al., 1968a ; Speizer et al., 1968b) to support the impression that the mortality rate from asthma has increased in this country in the last few years, particularly among younger patients. The reason for this increase is unknown, but it has coincided with the widespread use of pressurized sympathomimetic aerosols in the treatment of asthma, and these have therefore come under suspicion. Two possibilities are that overdosage with the active bronchodilator causes cardiac stimulation and eventually ventricular fibrillation (Greenberg and Pines, 1967) or that some asthmatics have a late bronchoconstrictor response to isoprenaline (Keighley, 1966). A third possibility is that the propellant or surfactant used in the pressurized aerosols might have a bronchoconstrictor action, particularly when taken in larger than recommended doses, since it is known that non-specific irritants of the tracheobronchial tree can initiate reflex bronchoconstriction (Widdicombe, Kent, and Nadel, 1962).

In the present study the body plethysmograph was used to measure changes in airway resistance, since this is the most sensitive method of following changes in bronchoconstriction (Lloyd and Wright, 1963) and allows a correction to be made for the effect of lung volume on airway resistance, and on its reciprocal, airway conductance. A deliberate overdose of 10 puffs of the aerosol was used to ensure that subjects unfamiliar with the technique of inhalation obtained an adequate dose, and to bring out any small effects.

It was found that aerosols, consisting of an inert propellant and surfactant only, caused slight bronchoconstriction in normal subjects, and it is uncertain which constituent was responsible. Although the response was slightly larger when the surfactant was changed from sorbitol trioleate to lecithin, suggesting that the latter had a constrictor action, the increase was not statistically significant. It remains possible that part of the response was due to the dichlordifluoroethane propellant. It should be stressed that, even with the lecithin aerosol, the response was too small to cause symptoms of wheezing, and the largest individual fall in SGaw was $25 \%$, which is close to the average fall found after inhalation of a single cigarette (Nadel and Comroe, 1961; Sterling $\underset{\overline{\mathrm{N}}}{\overrightarrow{\mathrm{s}}}$ 1967).

Since the inhalation of the aerosols frequentlyo caused coughing, they probably stimulated the irritant receptors in the tracheobronchial tree, $\bar{\Phi}$ which form part of the afferent limb of a vagally, mediated bronchomotor reflex (Widdicombe et al.", 1962). The response was tested again after inhala 0 tion of atropine and was found to be abolished which would support the hypothesis that it was. due to a vagal reflex. The bronchoconstriction is probably analogous to that caused by inhalation of cigarette smoke, inert carbon particles orf sulphur dioxide (Nadel, Salem, Tamplin, and Tokiwa, 1965).

The action of atropine is of interest in that the inhalation of only $0 \cdot 2 \mathrm{mg}$. produced broncho dilatation which was similar in degree to that reported after the injection of $1.2 \mathrm{mg}$. (Widdi combe et al., 1962). This finding agrees with thas of Altounyan (1964), who reported maximal in $\vec{c}$ crease in F.E.V., after inhalation of only $0.04 \mathrm{mg}$ of atropine methonitrate. Moreover, up to six times our dose (i.e., $1.2 \mathrm{mg}$.) could be inhalech without causing an increase in heart rate os symptomatic drying of the mouth, which suggest indirectly that it had little effect on bronchiaf secretions. The production of bronchodilatation shows that the atropine was more than adequat $\overrightarrow{5}$ to counteract any bronchoconstrictor effect of its own propellant and surfactant, as well as prevent? ing that due to subsequent inhalation of bronchiap irritants. The weak bronchoconstrictor action of sorbitol trioleate was more than balanced in nine normal subjects by the addition of isoprenaline to the aerosol.

The response of the small group of asthmatics. was essentially similar to that of the normab subjects, apart from a tendency to greate ${ }^{3}$ bronchoconstriction after inhalation of the aerosols. This agrees with previous suggestions that asthmatics show a more vigorous response to non-specific bronchoconstrictor stimuli than normal subjects (Altounyan, 1964).

It is impossible to exclude occasional idio $\tilde{O}$ syncracy to the propellants as a factor in asthmatic mortality, but no such cases have beero reported to date, and a large-scale survey would be needed to investigate this problem. What doef emerge from the present study is the finding that $t_{+}^{\circ}$ although the propellants used in two of the mosto popular aerosols have a bronchoconstrictor action this is too feeble, even in a large dose, to cause any symptomatic wheezing, and is therefore mos $\vec{D}$ unlikely to be a clinical hazard even if the propelo 
lants are combined with active agents other than bronchodilators. There is no evidence that other surfactants which we did not study, such as oleyl alcohol, are more irritant to the bronchi, and it is likely that the presence of a bronchodilator would be sufficient to overcome considerably greater bronchoconstrictor activity than that seen here. Although isoprenaline is very effective, atropine is a more specific antagonist of the propellantinduced bronchoconstriction because it blocks the effect of cholinergic neuromuscular transmission, and we have already suggested that the slight bronchoconstriction from inhaling aerosols is a vagally mediated reflex. It has the added advantage, when taken in a small dose by inhalation, of prolonging the action of isoprenaline (Chamberlain, Muir, and Kennedy, 1962) without causing any systemic effects or symptomatic drying up of secretions.

Our thanks are due to Miss F. A. Boother for her frequent technical help and to the subjects for their co-operation. The aerosols were kindly supplied by Riker Laboratories. During the course of this study G. M.S. was supported by a grant from the Board of Governors of St. George's Hospital, London, S.W.1.

\section{REFERENCES}

Altounyan, R. E. C. (1964). Variation of drug action on airway obstruction in man. Thorax, 19, 406.

Briscoe, W. A., and DuBois, A. B. (1958). The relationship between airway resistance, airway conductance and lung volume in subjects of different age and body size. J. clin. Invest., 37, 1279.

Butler, J., Caro, C. G., Alcala, R., and DuBois, A. B. (1960). Physiological factors affecting airway resistance in normal subjects and in patients with obstructive respiratory disease. Ibid., 39, 584.
Chamberlain, D. A., Muir, D. C. F., and Kennedy, K. P. (1962). Atropine methonitrate and isoprenaline in bronchial asthma. Lancet, 2, 1019.

DuBois, A. B., Botelho, S. Y., Bedell, G. N., Marshall, R., and Comroe, J. H., Jr. (1956). A rapid plethysmographic method for measuring thoracic gas volume: a comparison with a nitrogen washout method for measuring function

- - and Comroe, J. H., Jr. (1956). A new method for measuring airway resistance in man using a body plethysmograph: values in normal subjects and in patients with respiratory disease. Ibid., 35, 327 .

Freedman, B. I. (1967). Bronchodilator aerosols (letter). Lancet, $2,838$. Greenberg, M. J., and Pines, A. (1967). Pressurized aerosols in asthma (letter). Brit. med. J., 1, 563.

Guyatt, A. R., Alpers, J. H., Hill, I. D., and Bramley, A. C. (1967). Variability of plethysmographic measurements of air ways resistance in man. $J$. appl. Physiol., 22, 383.

Keighley, J. F. (1966). Iatrogenic asthma associated with adrenergic aerosols. Ann. intern. Med., 65, 985.

Kubler, H. (1964). Just how hazardous are propellants? The physiological properties of aerosol propellants. Aerosol Age, 9, April, p. 44.

Lloyd, T. C., Jr., and Wright, G. W. (1963). Evaluation of methods used in detecting changes of airway resistance in man. Amer. Rev. resp. Dis., 87, 529.

Nadel, J. A., and Comroe, J. H., Jr. (1961). Acute effects of inhalation of cigarette smoke on airway conductance. J. appl. Physiol., 16, 713.

_- Salem, H., Tamplin, B., and Tokiwa, Y. (1965). Mechanism of bronchoconstriction during inhalation of sulfur dioxide. Ibid., 20 164.

Pickvance, W. (1967). Pressurized aerosols in asthma (letter). Brit. med. J., $1,756$.

Plaut, G. S. (1967). Bronchodilator aerosols (letter). Lancet, 2, 721.

Smith, J. M. (1966). Death from asthma (letter). Ibid., 1, 1042.

Speizer, F. E., Doll, R., and Heaf, P. (1968a). Observations on recent increase in mortality from asthma. Brit. med. J., 1, 335.

_ - and Strang, L. B. (1968b). Investigation into use of drugs preceding death from asthma. Ibid., 1, 339.

Sterling, G. M. (1967). Mechanism of bronchoconstriction caused by cigarette smoking. Ibid., 3, 275.

Valtonen, E. J. (1967). Bronchodilator aerosols (letter). Lancet, 2, 1046.

Widdicombe, J. G., Kent, D. C., and Nadel, J. A. (1962). Mechanism of bronchoconstriction during inhalation of dust. J. appl. Physiol. 17,613 .

Zamel, N., Youssef, H. H., and Prime, F. J. (1963). Airway resistance, and peak expiratory flow-rate in smokers and non-smokers. Lancet. 1, 1237. 